\title{
Historical errors in the initial conception of the euro and its subsequent development
}

\author{
Erros históricos na concepção inicial do \\ euro e seu posterior desenvolvimento
}

DAVID RAMIRO TROITIÑO*

KAROLINE FAERBER**

\begin{abstract}
RESUMO: Em 1992, o Conselho Europeu lançou a União Econômica e Monetária (UEM). O início do euro seguiu-se em 1999. Desde então, a UEM sofreu avarias graves, sobretudo durante a recente crise da Zona Euro em 2010. Para compreender o atual enigma da Zona Euro (EZ), é necessário analisar as circunstâncias em que a UEM foi designada. Ao longo do seu desenvolvimento, o ex-presidente francês François Mitterrand provou ser uma figura central devido à sua capacidade de influenciar o processo de integração europeia. Contra o pano de fundo da reunificação alemã, Mitterrand conseguiu obter a criação de uma UEM da Alemanha. No entanto, ele depois falhou em impedir que a mesma união fosse moldada de acordo com o modelo alemão. Esta contribuição argumenta que a incapacidade de Mitterrand de formar a UEM de acordo com seus próprios ideais explica em parte os fracassos estruturais da EZ.

PALAVRAS-CHAVE: Euro; Zona Euro; crise da Zona Euro; União Monetária Europeia; François Mitterrand.
\end{abstract}

ABSTRACT: In 1992, the European Council launched the economic and monetary union (EMU). The inception of the euro followed in 1999. Ever since, the EMU has experienced severe malfunctions, not least during the recent Eurozone crisis of 2010. To understand the current Eurozone (EZ) conundrum, it is necessary to analyse the circumstances under which the EMU was designed. Throughout its development, former French President François Mitterrand proved to be a central figure due to his ability to influence the European integration process. Against the backdrop of German reunification, Mitterrand succeeded in obtaining the creation of an EMU from Germany. However, he thereafter failed to prevent the same union from being shaped according to the German model. This contribution argues that Mitterrand's inability to form the EMU according to his own ideals partly explains the structural failures of the EZ.

KEYWORDS: Euro; eurozone; eurozone crisis; European Monetary Union; François Mitterrand. JEL Classification: F5.

\footnotetext{
"Department of Law, Tallinn University of Technology, Tallinn, Estonia. E-mail: david.troitino@ttu.ee.

** Department of War Studies, King’s College London, London, UK. E-mail: karoline.faerber@kcl.ac.uk. Submitted: 9/April/2018; Approved: 29/October/2018.
} 


\section{INTRODUCTION}

In 2017, the Treaty on European Union (TEU) celebrated its $25^{\text {th }}$ anniversary. This treaty, better known as Maastricht Treaty, established the European economic and monetary union (EMU), which has become a matter of course today. In 1992, however, parts of the European population remained rather sceptical, ${ }^{1}$ while the treaty was celebrated among high-level politicians. French President François Mitterrand emphasised the importance of the TEU, stating that 'it is a moment that prepares for the following century' (PEF, 1991, 151-158). Mitterrand was by no means speaking just for himself but served as an example for the strong overall political will to further the integration of Europe through economic means (Moravcsik, 1999). ${ }^{2}$ Indeed, the TEU has transformed the European Communities (EC) and later the European Union (EU) significantly, most notably through the creation of the EMU with its purpose 'to promote economic and social progress which is balanced and sustainable' (European Communities, 1992). While EU institutions have claimed that the EMU has brought about significant benefits for those states participating in the Eurozone (EZ) (see, for example, European Commission, n.d.), its malfunctions are obvious.

The most recent and most severe failure of the EMU, the Eurozone crisis, commenced in 2010. Affecting government debt, the European economy and the banking structure of the EZ, the crisis has had substantial and lasting negative effects. One indicator is the development of government debt across the EZ. While the general government debt (in percent of GDP) of the EZ area increased by 17 percentage points from 2009 to 2014, the government debt of Greece, Spain and Portugal rose by 50 to 100 percent in the same period (Eurostat, 2017a). The crisis was enhanced by the fact that responses by the EZ institutions, including the European Central Bank (ECB), proved to be inadequate as they were severely limited in their actions by the lack of economic, fiscal, banking and political integration on the European level (Dyson, 2012). In fact, the ECB lacked the adequate means for crisis prevention and management (Dyson, 2012; Krugman, 2013; Stiglitz, 2016).

This observation raises the question of why - despite the strong will to create a political and economic union - has the EZ's institutional structure been designed in a way that made it prone to fail in times of crises? How can the lack of financial integration be explained if monetary integration was the declared objective of European leaders in the 1980 s and early 1990 s?

'It is a fault in the execution, not of the architects, declared former President of the European Commission, Jacques Delors (Kirkup, 2011), when asked about

\footnotetext{
${ }^{1}$ The French and the Danish were among the most doubtful towards the TEU, which was reflected their voting patterns during three national referendums. For a discussion on the Danish and French referendums of the TEU, see Denni (1993) and Worre (1995).

${ }^{2}$ See, for example, German Chancellor Helmut Kohl's speech before the German parliament on 4 December 1992 (Presse- und Informationsamt der Bundesregierung, 1992).
} 
the crisis facing the EMU. However, scholars have demonstrated that structural flaws had been built into the EMU from the outset (Hall, 2012; Caporaso \& Kim, 2012). Thus, in this context, it is necessary to analyse the origins of the TEU and the circumstances under which the EMU was designed, as Dyson and Featherstone (1999), amongst others, have done in great detail. They suggest that France, together with Germany, were central to the negotiations on the EMU. In this FrancoGerman partnership, François Mitterrand, who served as the French President from 1981-95, played a particularly central role in shaping the TEU (Saunier, 2013). Yet, Mitterrand proved to be unsuccessful in determining the institutional setting of the EMU. Overall, bilateral compromises between France and Germany severely limited the TEU's ambitions in the areas of institutional and economic governance, partly explaining the current EZ conundrum (Loth, 2013).

This paper builds on and advances Loth's argument as we clearly define the historical link between the misconceptions incorporated in the EMU's design and the Eurozone crisis. Aiming to take stock of and historicize the negotiations leading to the EMU, we employ the historical method of writing a 'micro-account' of the negotiations of the EMU. Thus, we strive to reconstruct the past in the sense of R. G. Collingwood. In this undertaking, we are significantly limited by the contingency of the past, which allows for various interpretations and assessments of historical events (Geary, Germond \& Patel, 2013, 5-6), as well as the lack of availability of sources. ${ }^{3}$ This paper follows an actor-centred approach based on the work by François Mitterrand for he developed a broad plan for the EZ's institutional structure. ${ }^{4}$ The plan, which we term his Grand Design, ${ }^{5}$ foresaw the economic integration of western European states to create a small, homogenous EMU. To this aim, Mitterrand envisaged the establishment of a European Confederation, which would defer eastern European states from being admitted to the European Communities after the dissolution of the USSR.

In the first section, we will discuss the historical backdrop against which Mitterrand's plan was developed. We will then examine the Grand Design itself. To fully understand the shortcomings of the EMU, we will analyse the Franco-German negotiations on its design in the third section. The conclusion will reflect on our findings and will establish the link between the negotiations on the TEU and the current Eurozone crisis.

\footnotetext{
${ }^{3}$ We will rely on both publicly accessible archival as well as contemporary sources.

${ }^{4}$ For a more detailed discussion of Mitterrand's plan, see Troitiño, Färber and Boiro (2017) as well as Mitterrand (1989b, 1990, 1996). In the following sections, we will outline those details necessary for our argument.

${ }^{5}$ The notion ‘Grand Design' was first used by Bozo to describe President de Gaulle's ambitions to create a 'Grande Europe' from the Atlantic to the Urals. Mitterrand based his plans for a European Confederation on this vision, which ultimately failed (Bozo, 2008, p. 393). From today's view, it is clear that the euro had a significant impact on creating such a 'Grande Europe', albeit on a more limited scale than previously imagined. Therefore, we find it appropriate to use the term in the context of the establishment of the EMU.
} 


\section{THE ORIGINS OF THE EMU}

The EMU was developed in a very different time than today. The end of the Cold War, the collapse of the USSR and German reunification changed the conceptions of Europe as well as the perceptions of the EC as an international actor (Christiansen, Duke \& Kirchner, 2012, 686). The TEU was part of a long-time process that had started with the creation of the European Coal and Steel Community in 1952. Particularly in the decade before and during the negotiations on the TEU, certain trends were present that help to explain the gradual shift towards the EMU and economic integration. To fully understand the origins of the EMU, it is thus necessary to briefly revisit the backdrop against which Mitterrand developed his Grand Design. We will discuss the impact of the Singly European Act (SEA) of 1986 and the European Monetary System (EMS), in place since 1979. Following Ludlow (2013), we will contextualise the SEA and the EMS in the perceived necessity of treaty change to further European integration, the need for institutional change in terms of the role of the European Council, and the tendency towards policy spill-over.

The 1960s and 1970s were marked by a process of informal change, which was widely perceived to be the reason for the slowing speed of European integration. As such, treaty change was seen as a necessary step to break the institutional stalemate, i.e., the so-called 'Euroclearosis', in which the EC seemed to be stuck by the early 1980s. ${ }^{6}$ The SEA of 1986 thus marked the beginning of the European monetary integration as it aimed at the creation of a single European market by January 1993 (Moravcsik, 1999, 314-378)..$^{7}$ Overall, the single market programme was perceived as a great success, strengthening ' $[\mathrm{t}]$ he association between treaty change and Community advance' (Ludlow, 2013, 13). The integration process was furthered by shifts in relative technological, industrial, and economic capabilities in favour of Europe and a failure of purely national economic strategies pursued by European countries (Sandholtz \& Zysman, 1989). In this context, the SEA foresaw, inter alia, integrating previous informal change into the treaty framework to eliminate the possibility of further informal change in the future. The SEA formalised a number of partly bilateral arrangements, including the gradual abolishment of national borders. As such, the Schengen Agreement of 1985 among France, Germany, and the Benelux countries stimulated the incorporation of previously national ambitions in European politics.

In addition, the SEA significantly altered the EC's institutional setting. Linking liberalization of the European market with procedural reform, the SEA modified the EC's decision-making process to a majority voting system that was binding

\footnotetext{
${ }^{6}$ The term 'Eurosclerosis' was coined by Herbert Giersch in 1985 to describe the slowing European integration process in the 1970s and early 1980s (Giersch, 1985). This, however, does not bear justice to the many achievements of this decade (see Awesti, 2009).

${ }^{7}$ For an overview on the SEA, see Green Cowles (2012).
} 
upon all member states but only applied to matters pertaining the single market (Moravcsik, 1991, 20). ${ }^{8}$ Furthermore, the European Council was firmly rooted within the EC's structure, recognising it centrality to the European integration process. As a result, the Council became the ultimate decision-making body with regards to the EMU (Christiansen, Duke \& Kirchner, 2012, 691).

The SEA's major aim, namely the establishment of a single European market, was, however, severely hindered by the prevailing border controls among European states. As the existing policies were directly opposed to the creation of a single market and the freedom of movement of people, capital, and goods inscribed in the SEA, the treaty created pressure for further policy change in the fields of border controls and monetary integration. A Franco-German agreement to gradually abolish border controls served as the starting point to the Schengen Agreement, "trigger[ing] a "spillover effect" from the bilateral to the European level and so deepen[ing] integration in the chosen area' (Germond, 2012, 200).

However, the still existing EMS proved to be a considerable stepping stone to the ambitious single market project. The EMS and its exchange-rate mechanism (ERM) had, thanks to its adjustable peg, provided stable exchange rates, but had increasingly advantaged Germany with its 'historical record of no devaluations' (Heisenberg, 2006, 235). Moreover, the EMS relied on capital controls in those countries with a weaker currency, such as France, thus contradicting the freedom of capital set forth in the SEA (Ludlow, 2013). Therefore, the single market programme implicitly threatened the EC's long-term stability, thereby creating a strong incentive to further advance the monetary integration, particularly for Mitterrand. ${ }^{9}$

\section{THE GRAND DESIGN}

The end of the Cold War and the collapse of the communist regimes in central and eastern Europe situated François Mitterrand at the epicentre of a critical moment in European history, enabling him to influence the design for the EZ institutions greatly. In the European integration process, Mitterrand took a leading role from 1984 onwards, elaborating on the economic necessity to restructure and revive Europe in various speeches (see, for example, Commission of the European Communities, 1984, 133-38). Mitterrand's policy towards Europe can be summarised under four main points: (1) priority of France's autonomy and independence vis-à-vis the USA and the USSR by using the EC's common resources; (2) confederation approach combined with critical decisions under the Council's control to further European integration; (3) internal consensus in France about its

\footnotetext{
${ }^{8}$ The majority voting system directly results from the perceived deadlock during the 1970s, when proceedings were hindered due to the continuous use of the veto by various member states.

${ }^{9}$ The Padoa-Schioppa report clearly made the case that the current status of the EMS was unsustainable (European Commission, 1987).
} 
European policy to achieve domestic political support; and (4) a key strategic relationship with Germany (see Tiersky, 1995). In this section, we will briefly outline Mitterrand's vision.

\section{THE EUROPEAN CONFEDERATION}

Mitterrand first raised the idea of a Confederation of European states in December 1989. The success of the SEA and the single market had significantly increased the EC's attractiveness to prospective member states (Dinan, 2012, 845-46). Thus, Mitterrand envisaged the creation of a European Confederation, which would establish a constant dialogue between the EC and eastern and central European countries but would defer the latter from being admitted to the EC in due time (see also Mitterrand, 1990).

Warning of fragmentation and disintegration, Mitterrand stated:

Europe will no longer be the Europe we have known for half a century. [...] Either the tendency to rupture, to dissipation will increase and we will find us again in the Europe of 1919 [...] or Europe will be built. She can do this in two stages, first of all through our community of Twelve, which must definitely strengthen its structures. [...] The second stage remains to be invented: on the basis of the Helsinki agreements, I expect to see the birth of a European Confederation, in the true sense of the word, in the 1990s, which will involve all states of our continent in a common organization with continuous exchange, peace and security. (Mitterrand, $1989 b) .{ }^{10}$

To succeed in 'building bridges' (Mitterrand, 1989a), Mitterrand envisaged a European Confederation consisting of three differentiated areas or circles: (1) an integrated federalist western Europe under French leadership; (2) a common market including central and eastern Europe; and (3) political dialogue and cooperation with the USSR in limited policy areas. The Confederation would thus serve as a way to 'affirm the common European identity of the former satellite states [of the USSR] during what he [Mitterrand] saw as a lengthy transition period when their economic backwardness would preclude them from joining the European Community' (Short, 2013, 482). ${ }^{11}$ In addition, a Confederation would frame Russia, which remained a potentially threatening power (Saunier, 2013, 46). At the heart of this common Europe remained the EC with its Franco-German core (Mitterrand,

\footnotetext{
${ }^{10}$ Translated from French to English by the authors. See also Mitterrand's speech before the European Parliament in November 1989 (European Parliament, 1989).

${ }^{11}$ For a detailed account of the economic level of the former countries of the Soviet bloc, see Berend (2016, pp. 177-91).
} 
1996), allowing for the irreversible anchoring of a newly reunified Germany in a strengthened EC and a consolidation of French control over the EC (Musitelli, 2011, 21). In Mitterrand's view, German reunification and deeper integration had to go hand in hand to ensure a binding and irreversible solidarity between the EC in general and the Franco-German core in particular (Saunier, 2013, 46). Mitterrand was motivated by a deep fear of the power of a newly strengthened Germany, causing him to be sceptical towards the possibility of German reunification at first (Salmon \& Hamilton, Twigge, 2012, 215-19). 'Everything will remain under control if progress towards ending Germany's division does not proceed faster than that in the construction of Europe', Mitterrand's advisor Védrine stated (note from Hubert Védrine, 18 October 1989, quoted in Bozo, 2012, 152-53). This also reflected the perceived necessity of deferring eastern European states from accession to the EC as this region largely remained Germany's sphere of influence.

The 'growing demand on the part of countries of central and eastern Europe for access to western institutions against the backdrop of a perceived security vacuum' (Bozo, 2008, 406) made them, however, reticent to a Confederation that would most likely delay this access. Mitterrand clashed with his most prominent ally Helmut Kohl over geopolitical priorities, with Germany firmly advocating for the wishes of its eastern neighbours. ${ }^{12}$ Members of the French government and Mitterrand's political advisors remained equally sceptical (Dumas, 2001; Védrine, 1996, 448; Védrine \& Musitelli, 1991). When the USA finally rejected a European Confederation in total and a conference on the launch of the project failed, Mitterrand admitted that his plan had at least been postponed, if not cancelled (Mitterrand \& Havel, 1998, 126-54; see also Saunier, 2011). It became apparent that the Confederation had failed altogether when the EC directed their attention towards the TEU, which explicitly states the possibility of the admission of new member states.

\section{THE EUROPEAN MONETARY UNION}

The establishment of an EMU was by no means a new idea, ${ }^{13}$ yet it was significantly advanced by Mitterrand during the 1990s. Mitterrand envisaged a small, homogenous EMU, which can be understood as an optimum currency area (OCA) (see Kenen, 1969; McKinnon, 1963; Mundell, 1961). An OCA is 'an economic unit composed of regions affected symmetrically by disturbances and between which

\footnotetext{
${ }^{12}$ See Newton (2013) for an interesting discussion on how Mitterrand became a 'source of pan-European division' through his proposal for a pan-European structure.

${ }^{13}$ The Werner Plan of 1970 proposed, for the first time, the creation of a monetary union in Europe. It failed when European politicians were not prepared to advance with a proposal that foresaw significant political integration. When the Bretton Woods system that had established a monetary order among the USA, Canada, Australia, Japan and Western Europe since 1944 was brought to an end in 1971, European countries tried to ensure currency stability on a regional basis, including the "Snake" and the EMS, to peg exchange rates against the dollar (see Eichengreen, 2007, pp. 163-293).
} 
labour and other factors of production flow freely' (Eichengreen, 1998, 51). For the EC comprised states with a similar economic performance and labour was increasingly mobile, an EMU would have been close to an OCA. ${ }^{14}$ Hence, it would have been economically stable in times of crises. Mitterrand, however, rather focused on the political advantages of an EMU. In fact, he pursued three goals: 'first, they [the French] saw [the EMU] as a necessary element of a policy of economic growth on the European level; second, they strove for independence from the erratic movements of the dollar and the US policy of interest; third they aimed at destroying the hegemonic position of the German Bundesbank' (Loth, 2013, 67; see also Dyson and Featherstone, 1999; Saunier, 2013). Due to its strong monetary and fiscal position, Germany was able to control the EC economically through the EMS. Hence, Mitterrand aspired to consolidate French influence over communitarian affairs by introducing the EMU to maintain price stability and to establish a federal system of central banks (Abdelal, 1998, 254-57; Sandholtz, 1993b, 127). In other words, to him there had to be a balance between the monetary and the economic aspects of the EMU (Saunier, 2013, 59; see also Guigou, 2004).

The emphasis on democratic control of the central bank and the monetary policy was rooted in the French economic model (see Thiemeyer, 2013). To Mitterrand and to the French government, the state remained the sole point of reference concerning economic policies because the nation-state was the sole democratically legitimised decision-making body on the European level (Mitterrand, 1990). Consequently, Mitterrand reaffirmed that 'Europe is composed of nations' (Mitterrand, 1988, translated by the authors). As sovereign politics prevailed over supranational autonomous structures, the European Council was to be strengthened with regards to economic policies (Archives Nationales, n.d.). In addition, a federal system of central banks would have allowed for a coordinated yet supranationally controlled fiscal policy.

In contrast, Germany argued for strict central bank independence. As Germany accentuated the need for free market operation and monetary stability, its reluctance towards the EMU resulted from the fear of an 'inflation-union' (Loth, 2013, 67). Despite a seemingly economic focus, the EMU was hence driven mainly by political rather than purely economic factors, including interstate bargaining to reduce German influence over European monetary policy (Eichengreen and Frieden, 1993).

In addition, German reunification also influenced Mitterrand's plans for his European construction in general and the EMU in particular (see Mitterrand, 1996). Within his European Confederation, the first circle was to be firmly integrated by a common currency and a common market. Mitterrand's EMU was based on a

\footnotetext{
${ }^{14}$ It is important to note that Kenen (1969) called for a centralised fiscal policy, which implies de facto a political union. Most OCA concepts also regard factor mobility, including labour mobility, as key precondition for a monetary union. It has been shown, and is clear from the following sections, that neither criterion has been fulfilled in the EZ. We thank one anonymous reviewer for pointing this out.
} 
Europe of the Twelve, closely integrated by a common currency and surrounded by a strong European Confederation that respected the states' diversity (Saunier, 2013, 50). Therefore, Mitterrand aspired to satisfy French security interests through firmly anchoring a newly unified Germany in Europe (see Dyson, 1994). Consequently, Mitterrand presented the EMU in historical accordance with French interests (Archives Nationales, 1991e).

\section{THE NEGOTIATIONS ON EMU}

Both the political and economic premises seemed favourable to Mitterrand's design: ${ }^{15}$ during his presidency, French political domination of the European integration process was at its peak. In addition, the single market project triggered a 'broad wave of pro-EC enthusiasm' (Sandholtz, 1993a, 4), further enabling him to initiate change. Due to the political insecurity caused by German reunification, Mitterrand took special care to guarantee that the TEU was rendered 'irreversible' (Archives Nationales, 1991c; Archives Nationales, 1991d). Thus, his strategy was to closely watch the German government and to ensure that there was a solid Franco-German agreement at every stage when negotiating the TEU (Archives Nationales, 1991a; Archives Nationales, 1991b). This included a 'binding-in' of the German Bundesbank to commit the German government to the EMU.

After previous initiatives to establish an EMU had failed, the debate was relaunched in 1988. At its Hannover Summit, the European Council mandated a committee chaired by Commission President Jacques Delors to propose a plan for the implementation of the EMU, including a common currency. The ensuing Delors Report of 1989 presented a three-stage roadmap for the EMU. While it adhered to Mitterrand's wish to establish a common currency, it already incorporated the German model, including an independent central bank system led by an ECB. It did so against Mitterrand's will but with his silent approval once he realised that he did not have a practical alternative (Dyson \& Featherstone, 1999, 124-25). Overall, the report lacked a clear outline of a common economic and fiscal policy, referring instead to broad macroeconomic policies. On other aspects, including a timeframe and the organization of the transition, the report stayed just as vague despite pressure from the French representative. As the ultimate responsibility remained with the member states, the German Bundesbank 'retained the fundamental essentials regarding the shape of the future monetary union' (Loth, 2013, 69). However, the report still gave a strong impulse to further develop the EMU during two intergovernmental conferences.

Therefore, Mitterrand set up a working group to prepare the next steps and suggested a clear timeframe (Clavert, 2008). Due to the German national elections

\footnotetext{
15 On the change in the mainstream economic doctrine that made an EMU seem economically viable, see Hall (2012).
} 
in December 1990, Kohl pushed for a delay of the conferences, proposing to postpone the political decision on the EMU until after election day (Bundesministerium des Innern, 1998, 565-67). In Paris, this was perceived as a practical rejection of the EMU (Attali, 1995, 349). Threatening to withhold French approval of German reunification, Mitterrand demanded three commitments from Germany: 'the beginning of negotiations on the monetary union, the definitive recognition of Germany's border with Poland, and confirmation of the Federal Republic's renunciation of nuclear weapons' (Loth, 2013, 71; see also Attali, 1995, 353-354). To not endanger both the reunification and the European integration, Kohl gave in on the EMU and agreed to a date for the first intergovernmental conference (see Lappenküper, 2011, 269-271). In return, the European Council decided that stages two and three were not to begin until the necessary preparations had been made.

Franco-German controversies about the exact setting of the EMU remained. While Kohl emphasized that the EMU had to be accompanied by a political union (Christlich Demokratische Union Deutschlands, 1992, 167; European Parliament, 1989, 156), to Mitterrand, the EMU logically followed the single market and preceded a political union. Over the course of the German unification, Mitterrand's stance was influenced by his advisor Élisabeth Guigou. Commenting on a suggestion by Jacques Delors to accompany the EMU with a political union (see Commission of the European Communities, 1990, 6-16), she wrote to Mitterrand:

The Community has an interest in inventing very quickly an institutional armature that would make the German situation banal [...] [to] assure that Germany determines its orientations within the framework of the Community and not autonomously. [...] Better for the European Union to be negotiated with Germany still provisionally divided into two states and needing the Community, rather than with a reunified Germany that will no longer have need of anybody (note from Élisabeth Guigou, $6 \mathrm{Fe}-$ bruary 1990; quoted in Bozo, 2010, 185).

For this reason, Guigou proposed a transformation of the EC into a political union, yet under French rather than German terms. That included a much more intergovernmental approach than Germany thought feasible. When German unification appeared as fait accompli in summer 1990, Mitterrand adopted Guigou's approach, advancing towards both EMU as well as political union at the same time (Mitterrand, 1990; Attali, 1995, 606). Under his guidance, the EC embraced the reunification of East and West Germany. In return, Kohl was forced to proceed with the implementation of the EMU (Clavert, 2008). ${ }^{16}$ The German reunification, however, lessened German pressure on France to make further progress in the negotiations on the political union (Heisenberg, 2006, 239). At the Council meeting in

\footnotetext{
${ }^{16}$ See the numerous joint Franco-German declarations, i.e., CVCE, 2014; Presse und Informationsamt der Bundesregierung, 1990a; Presse- und Informationsamt der Bundesregierung, 1990b.
} 
Rome in October 1990, Kohl agreed to a compromise on the timeframe for the second stage and gave in to the growing pressure to accept Italian Prime Minister Andreotti's suggestion to transition to the currency union no later than 1 January 1999 (Dyson \& Featherstone, 394-401).

Overall, negotiations were marked by Franco-German compromises on essential features of the EMU. Notably, much preparatory work for the design of the ECB was carried out by the Committee of Governors of the Member Countries of the European Communities (CoG) on behalf of the European Council. As the CoG mainly comprised central bankers, they were eager to ensure two essential principles throughout their work: price stability and the centralization of monetary policy (James, 2013, 111). The German Bundesbank in particular emphasised the importance of an independent central bank as well as its powers in exchange-setting policy, which greatly influenced the negotiations. As Dyson $(2012,795)$ reaffirms, ' $[t]$ he negotiating positions of the leading negotiators of the Maastricht Treaty were framed and constrained by the strategy of 'binding-in' the German Bundesbank to the final outcome'. For the CoG presented a draft of the ECB statute within a month after it had started its work in early 1990, much of the preparatory work had been completed by the beginning of the intergovernmental conferences in December 1990.

Two of the remaining questions were the creation date of the ECB and the design of economic convergence criteria. While Germany wanted economic convergence as a precondition for the EMU, France argued for a quick transition to the EMU to facilitate this economic convergence (Heisenberg, 2006, 238). The compromise reached between Mitterrand and Kohl was that France would accept strict convergence criteria in return for Germany's agreement to a later creation of the ECB. Subsequently, the Commission developed the following criteria: the government budget deficit had to be below three per cent of a state's GDP, the ratio of government debt to GDP had to be fixed at 60 per cent, the average rate of inflation and their nominal long-term interest rate had to be below the performance of the three economically strongest member states by 1.5 and 2 per cent, respectively, and the state had to be a member of the ERM without devaluation for two consecutive years.

After this major compromise, technicalities were settled over the course of 1991. On 7 February 1992, the foreign and finance ministers of the EC member states signed the TEU. Following Mitterrand's vision, the treaty set a deadline for the adoption of the EMU, established price stability as the overriding mandate of the EMU and introduced a federal system of independent European central banks (Sandholtz, 1993, 127). In return, he followed Kohl's wish to create an autonomous ECB on the model of the German Bundesbank. Two factors that help explain the concessions made by Mitterrand include the imperative of the creation of a solidary EMU that includes the Deutschmark (Saunier, 2013, 49) as well as the German reunification process. As Marsh $(2009,133)$ reaffirms, 'the fusing of the two Germanys, and the birth of the single currency, are intimately intertwined. If unification had not happened, it is highly unlikely that France would have been able to persuade Kohl to agree the EMU timetable to replace the D-Mark by the Euro.' 


\section{CONCLUSION}

François Mitterrand's Grand Design has left its print on the institutional setting of the EZ. He envisaged a small, western European based EC, firmly integrated by a common currency and seconded by a loose Confederation of European states. Although he succeeded in obtaining an EMU from Germany, he failed thereafter to prevent the same union from being shaped according to the German model.

As a result, there was no Europe-wide fiscal authority to complement the monetary authority of the ECB, thus producing two 'fundamental flaws' as fiscal policies were left entirely to the EZ member states: 'the mechanisms for enforcing fiscal discipline were inadequate, and there was no Europe-wide banking supervision and regulation' (James, 2012, 16). This is particularly important if there is an asymmetrical crisis. An asymmetrical crisis is a shock to the economic system that affects various parts of the system with varying degrees of severity, as happened during the Eurozone crisis of 2010. Such asymmetrical crisis does not necessarily create a case for policy autonomy if alternative means such as labour mobility and real wage flexibility exist (Eichengreen \& Frieden, 1993, 92) or if there is a centralised fiscal policy. This is not the case in the EZ. Hence, " $[t]$ he deficits of an "economic governance" largely complained during the present-day "Euro-crisis" are mainly the result of the influence of the German Bundesbank insisting on the independence of a European Central Bank' (Loth, 2013, 83). While this is true, the continuing enlargement of the EZ as well as the convergence criteria of the TEU help to explain the current EZ conundrum in greater detail.

The enlargement of the EZ to currently 19 highly heterogeneous members (see Schwab, 2015) has increased the possibility of an asymmetric crisis. As has been shown in this paper, Mitterrand's design of an EMU was based on a homogenous core, which can be understood as an OCA. Today, the EZ is far from being an OCA due to its continuing enlargement (Hall, 2016; Eichengreen, 2015; Jager \& Hafner, 2013). Notably, Mitterrand did not envisage the admission of a great number of new members until many years after the EMU had been established. However, this proved to be politically unattainable. After reunification, Germany took on a greater role in the European integration process due to its economic performance and geostrategic role between western and eastern Europe, acting as a mediator and spokesperson for the former communist bloc. ${ }^{17}$ The ensuing enlargement of the EZ then set the path for a division into core and periphery, with a drastic augmentation of public debt particularly in the latter during the Eurozone crisis.

Interestingly, the public debt of some of the founding states of the EC such as Italy was among the highest during the Eurozone crisis in 2010. This was due to the fact that a number of EZ member states had been admitted to the EMU without meeting the convergence criteria in the first place. Although the convergence criteria

\footnotetext{
${ }^{17}$ See Moravcsik and Vachudova (2003) for a discussion on why the EU's eastern enlargement was politically viable and thus inevitable in the end.
} 
of the TEU did not allow for much manoeuvring room, they were much more flexibly handled in practice than the text itself suggests (see European Commission, 1998). While most states succeeded in lowering their budget deficit significantly, the public debt of certain member states, including EC founding states such as Belgium, fluctuated widely. Yet, the European Commission deemed Belgium to have converged to the criteria in 1998. Furthermore, Italy had not been part of the EMS between September 1992 and November 1996, thereby not reaching the required two years of membership in the ERM. Due to its important political position, it too was deemed to have converged. The Stability and Growth Pact of 1997 then institutionalised the criteria but was suspended on the initiative of France and Germany in 2003. In the following, fiscal convergence further deteriorated (see also James, 2012, 16-20).

François Mitterrand's Grand Design was partly implemented in the EZ. This paper has analysed the negotiations between France and Germany to show how bilateral compromises severely limited the TEU's ambitions in the areas of institutional and economic governance. These structural misconceptions have partly prevailed today, limiting the means of the EMU to make it viable in the long-run. Therefore, the authors agree with the majority of scholars who hold that EZ's institutional structure must be continually reformed in order to meet today's requirements (see also Krugman, 2013; Le Heron, 2015; Stiglitz, 2016; Tsoukalis, 2014).

\section{REFERENCES}

Abdelal, R. 1998. "The Politics of Monetary Leadership and Followership: Stability in the European Monetary System since the Currency Crisis of 1992." Political Studies 46 (2): 236-59.

Archives Nationales. N.d. PHB.8-4, Institutional questions.

Archives Nationales. 1991a. PHB.9-1, European Council: Political Union, 22 November 1991.

Archives Nationales. 1991b. CDM.14-1, Position of the Delegation, 25 November 1991.

Archives Nationales. 1991c. CDM.14-1, Minutes of the interdepartmental meeting on the 25 November 1991, 26 November 1991.

Archives Nationales. 1991d. CDM.14-1, General Secretariat of the Government, Minutes of the Meeting of Ministers held on 28 November 1991, 2 December 1991.

Archives Nationales. 1991e. PHB.9-1, Letter from Matignon, December 1991.

Attali, J. 1995. Verbatim, III: Chronique des années 1988-1991. Paris: Fayard.

Awesti, A. 2009. “The Myth of Eurosclerosis: European Integration in the 1970s." L'Europe en Formation 3 (353-354): 39-53.

Bayoumi, T. and B. Eichengreen. 1993. "Shocking Aspects of European Monetary Unification." In Adjustment and Growth in the European Monetary Union, edited by F. Torres and F. Giavazzi, 193-229. Cambridge: Cambridge University Press.

Berend, I.T. 2016. The History of European Integration. A new perspective. London/New York: Routledge. Bozo, F. 2008. "The Failure of a Grand Design: Mitterrand's European Confederation, 1989-1991." Contemporary European History 17 (3): 391-412.

Bozo, F. 2010. Mitterrand, the End of the Cold War, and German Unification. $2^{\text {nd }}$ ed. New York/Oxford: Berghahn Books.

Bozo, F. 2012. "France, German unification and European integration." In Europe and the End of the Cold War: A Reappraisal, edited by F. Bozo, M.-P. Rey, and N. P. Ludlow, 148-60. London/New York: Routledge.

Bundesministerium des Innern, ed. 1998. Deutsche Einheit. Sonderedition aus den Akten des Bundeskanzleramtes 1989/90. Munich: Oldenbourg. 
Caporaso, J., and M.-h. Kim. 2012. “The Maastricht Treaty at Twenty: A Greco-European Tragedy?.” Journal of European Integration 34 (7): 769-89.

CVCE. 2014. Gemeinsame Botschaft von François Mitterrand und Helmut Kohl (Bonn, 18. April 1990). Available online at https:/www.cvce.eu/obj/gemeinsame_botschaft_von_francois_mitterrand_und_ helmut_kohl_bonn_18_april_1990-de-89369c53-5d93-4e56-8397-825ca92c86f5.html.

Christiansen, T., S. Duke, and E. Kirchner. 2012. "Understanding and Assessing the Maastricht Treaty." Journal of European Integration 34 (7): 685-98.

Christlich Demokratische Union Deutschlands. 1992. Protokoll des 3. Parteitages der Christlich Demokratischen Union Deutschlands, Düsseldorf, 26.-28. Oktober. Available online at http://www. kas.de/upload/ACDP/CDU/Protokolle_Parteitage/1992-10-26-28_Protokoll_03.Parteitag_Duesseldorf.pdf.

Clavert, F. 2008. Transcription de l'interview d'Élisabeth Guigou (Paris, 29 septembre 2008). Available online at: https://www.cvce.eu/content/publication/2016/8/17/2ce69748-3edc-47e7-8842d2cb14b1f0eb/publishable_fr.pdf.

Commission of the European Communities. 1984. Bulletin of the European Communities, Vol. 17, No. 5. Commission of the European Communities. 1990. Bulletin of the European Communities, Supplement $1 / 90$.

Denni, B. 1993. „Du référendum du 20 septembre 1992 sur l'Union européenne aux élections législatives de mars 1993." In Le vote sanction. Les élections législatives des 21 et 28 mars 1993, edited by P. Habert, P. Perrineau, and C. Ysmal, 89-109. Paris: Presses de Sciences Po.

Dinan, D. 2012. "The Arc of Institutional Reform in Post-Maastricht Treaty Change." Journal of European Integration 34 (7): 843-58.

Dumas, R. 2001. “Un projet mort-né : la Confédération européenne.” Politique étrangère 66 (3): 687-703.

Dyson, K. 1994. Elusive Union: The Process of Economic and Monetary Union in Europe. London: Longman.

Dyson, K. 2012. “'Maastricht Plus': Managing the Logic of Inherent Imperfections.” Journal of European Integration 34 (7): 791-808.

Dyson, K. and K. Featherstone. 1999. The Road to Maastricht. Negotiating Economic and Monetary Union. Oxford University Press, Oxford.

Eichengreen, B. 1998. European Monetary Unification: Theory, Practice, and Analysis. $2^{\text {nd }}$ ed. Cambridge: MIT Press.

Eichengreen, B. 2007. The European Economy Since 1945: Coordinated Capitalism and Beyond. Princeton: Princeton University Press.

Eichengreen, B. 2016. Hall of Mirrors. The Great Depression, the Great Recession, and the Uses-and Misuses - of History. Oxford: Oxford University Press.

Eichengreen, B. and J. Frieden. 1993. "The Political Economy of European Monetary Unification: An Analytical Introduction." Economics and Politics 5 (2): 85-104.

European Commission (n.d.) What is the Economic and Monetary Union? Available online at: https:// ec.europa.eu/info/business-economy-euro/economic-and-fiscal-policy-coordination/economic-and-monetary-union/what-economic-and-monetary-union-emu_en.

European Commission. 1987. "Efficiency, stability, and equity: a strategy for the evolution of the economic system of the European community." Available online at: http://ec.europa.eu/archives/emu_history/documentation/chapter12/19870410en149efficiencstabil_a.pdf.

European Commission. 1998. European Economy, No. 65. Available online at: http://ec.europa.eu/economy_finance/publications/pages/publication8013_en.pdf.

European Communities. 1992. Treaty on European Union. Official Journal of the European Communities, Vol. 35, No. C-191.

European Parliament. 1989. Debates of the European Parliament. Report of Proceedings from 20 to 24 November 1989. Official Journal of the European Communities, No. 3-383.

Eurostat. 2017a. General government gross debt. Available online at http://ec.europa.eu/eurostat/tgm/table.do?tab=table\&init $=1 \&$ language $=$ en $\&$ pcode $=$ tsdde $410 \&$ plugin $=1$.

Eurostat. 2017b. Provision of deficit and debt data for 2016 - first notification. Available online at http:// ec.europa.eu/eurostat/documents/2995521/7997684/2-24042017-AP-EN.pdf/d83f50f3-ecab$457 \mathrm{a}-\mathrm{a} 46 \mathrm{~b}-\mathrm{f} 58 \mathrm{~d} 3 \mathrm{e} 42 \mathrm{a} 030$. 
Geary, M. J., C. Germond, and K. K. Patel. 2013. “The Maastricht Treaty: Negotiations and Consequences in Historical Perspective - Introduction." Journal of European Integration History 19 (1): 5-9.

Germond, C. 2012. "Dynamic Franco-German Duos: Giscard-Schmidt and Mitterrand-Kohl." In The Oxford Handbook of the European Union, edited by E. Jones, A. Menon, and S. Weatherill, 193205. Oxford: Oxford University Press.

Giersch, H. 1985. "Eurosclerosis." Lecture delivered in Sydney on August 20, 1985, at the Regional Meeting of the Mont Pelerin Society.

Green Cowles, M. 2012. "The Single European Act.” In The Oxford Handbook of the European Union, edited by E. Jones, A. Menon, and S. Weatherill, 107-20. Oxford: Oxford University Press.

Guigou, E. 2004. "Le Traité de Maastricht : la dernière grande oeuvre européenne de François Mitterrand." La lettre de l'Institut François Mitterrand 8: 22-23.

Hall, P. A. 2012. “The Economics and Politics of the Euro Crisis.” German Politics 21 (4): 355-71.

Hall, P. A. 2016. "The Euro Crisis and the Future of European Integration.” In The Search for Europe. Constructing Approaches, 46-67. Madrid: BBVA.

Heisenberg, D. 2006. "From the Single Market to the Single Currency." In Origins and Evolution of the European Union, edited by Desmond Dinan, 233-52. Oxford: Oxford University Press.

Jager, J. and K. A. Hafner. 2013. 'The Optimum Currency Area Theory and the EMU.” Intereconomics 48 (5): 315-22.

James, H. 2012. Making the European Monetary Union. Cambridge/London: The Belknap Press.

James, H. 2013. "Designing a Central Bank in the Run-Up to Maastricht.” Journal of European Integration History 19 (1): 105-22.

Kenen, P. 1969. “The Theory of Optimum Currency Areas: An Eclectic View”. In Monetary Problems of the International Economy, edited by R. Mundell, and A. Swoboda, 41-60. The University of Chicago Press: Chicago.

Kirkup, J. 2011. 'Euro doomed from start, says Jacques Delors'. The Telegraph. Available online at http:// www.telegraph.co.uk/finance/financialcrisis/8932647/Euro-doomed-from-start-says-Jacques-Delors.html.

Krugman, P. 2013. "The Revenge of the Optimum Currency Area.” In NBER Macroeconomics Annual 2012, edited by D. Acemoglu, J. Parker, and M. Woodford, 429-48. Chicago: University of Chicago Press.

La Politique Étrangère de la France : textes et documents. 1991. "November-December 1991.“

Lappenküper, U. 2011. Mitterrand und Deutschland. Die enträtselte Sphinx. Munich: Oldenbourg.

Le Heron, E. "L'euro, une monnaie incomplète : retour sur les ambiguités du compromis historique, politique et idéologique lors de la création de la BCE." Économie et institutions 22: 179-210.

Loth, W. 2013. "Negotiating the Maastricht Treaty.” Journal of European Integration History 19 (1): $67-$ 83.

Ludlow, N. P. 2013. “European Integration in the 1980s: on the Way to Maastricht?.” Journal of European Integration History 19 (1): 11-22.

Marsh, D. 2009. The Euro: The Politics of the New Global Currency. New Haven: Yale University Press.

McKinnon, R. I. 1963. “Optimum Currency Areas.” The American Economic Review 53 (4): 717-25.

Mitterrand, F. 1988. Interview de M. François Mitterrand, Président de la République, accordée à FR3 le 8 novembre 1988. Available at http://discours.vie-publique.fr/notices/887028100.html.

Mitterrand, F. 1989a. Conférence de presse de M. François Mitterrand, Président de la République sur la politique étrangère de la France, Paris, 18 May. Available at http://discours.vie-publique.fr/notices/897010200.html.

Mitterrand, F. 1989b. Voeux du président de la République, 31 December. Available at http://www.ina.fr/ video/CAB90000172.

Mitterrand, F. 1990. Conférence de presse de M. François Mitterrand, Président de la République, à l'issue du Conseil européen, 15 December. Available at: http://discours.vie-publique.fr/notices/907025900.html.

Mitterrand, F. 1996. De l'Allemagne, de la France. Paris: Odile Jacob.

Mitterrand, F. and V. Havel. 1998. Prague 1991. Assises De La Confédération Européenne. La Tour d'Aigues: Éditions de l'aube.

Moravcsik, A. 1991. "Negotiating the Single European Act: National Interests and Conventional Statecraft in the European Community." International Organization 45 (1): 19-56. 
Moravcsik, A. 1999. The Choice for Europe: Social Purpose and State Power from Messina to Maastricht. London: UCL Press.

Moravcsik, A. and M. A. Vachudova. 2003. "National Interests, State Power, and EU Enlargement.” East European Politics and Societies 17 (1): 42-57.

Mundell, R. A. 1961. "A Theory of Optimum Currency Areas.” The American Economic Review 51 (4): 657-65.

Musitelli, J. 2011. "François Mitterrand, Architecte De La Grande Europe : Le Projet De Confédération Européenne (1990-1991).” La Revue Internationale et Stratégique 2 (82): 18-28.

Newton, J. M. 2013. "Gorbachev, Mitterrand, and the Emergence of the Post-Cold War Order in Europe." Europe-Asia Studies 65 (2): 290-320.

Presse- und Informationsamt der Bundesregierung. 1990a. Gemeinsame Erklärung anlässlich der deutsch-französischen Konsultationen am 17. und 18. September 1990 in München. Bulletin des Presseund Informationsamtes der Bundesregierung, No.111-90.

Presse- und Informationsamt der Bundesregierung. 1990b. Gemeinsame Botschaft von Bundeskanzler Dr. Helmut Kohl und dem Präsidenten der französischen Republik, François Mitterrand, an den Präsidenten des Ministerrates. Bulletin des Presse- und Informationsamtes der Bundesregierung, No. 144-90.

Presse- und Informationsamt der Bundesregierung. 1992. In einem vereinten Europa dem Frieden der Welt dienen - Rede des Bundeskanzlers vor dem deutschen Bundestag. Bulletin des Presse- und Informationsamtes der Bundesregierung, No. 130-92.

Salmon, P., K. Hamilton, and S. R. Twigge, eds. 2012. German Unification 1989-90. Documents on British Policy Overseas, Series III, Volume VII. London/New York: Routledge.

Sandholtz, W. 1993a. "Choosing Union: Monetary Politics and Maastricht." International Organization 47 (1): 1-39.

Sandholtz, W. 1993b. “Monetary Bargains: The Treaty on EMU.” In The State of the European Community, Vol. 2: The Maastricht Debates and Beyond, edited by A. Cafruny, G. G. Rosenthal, 125-42. Burnt Mill: Longman.

Sandholtz, W. and J. Zysman. 1989. "1992: Recasting the European Bargain.” World Politics 42 (1): 95-128.

Saunier, G. 2011. "De la Communauté à l'Union européenne. L'action européenne de François Mitterrand (1981-1995).“ Matériaux pour l'histoire de notre temps 101-102 (1): 20-28.

Saunier, G. 2013. "La négotiation de Maastricht vue de Paris.” Journal of European Integration History 19 (1): 45-65.

Schwab, K. 2015. “The Global Competitiveness Report 2015-2016.” Geneva: World Economic Forum.

Short, P. 2013. Mitterrand. A study in ambiguity. London: The Bodley Head.

Stiglitz, J. 2016. The Euro. How a Common Currency Threatens the Future of Europe. New York: W. W. Norton.

Thiemeyer, G. 2013. "Economic Models in France and Germany and the Debates on the Maastricht Treaty." Journal of European Integration History 19 (1): 85-104.

Tiersky, R. 1995. “Mitterrand's Legacies.” Foreign Affairs 74 (1): 112-21.

Troitiño, D. R., K. Färber, and A. Boiro. 2017. "Mitterrand and the Great European Design: From the Cold War to the European Union.” Baltic Journal of European Studies 7 (2): 132-47.

Tsoukalis, L. 2014. The Unhappy State of the Union. Europe Needs a New Grand Bargain. London: Policy Network.

Védrine, H. 1996. Les mondes de François Mitterrand. Paris, Fayard.

Védrine, H. and J. Musitelli. 1991. "Les changements des années 1989-1990 et l'Europe de la prochaine décennie.” Politique étrangère 56 (1): 165-77.

Worre, T. 1995. "First No, Then Yes: The Danish Referendums on the Maastricht Treaty 1992 and 1993." JCMS: Journal of Common Market Studies 33 (2): 235-57. 